\title{
Evaluation of Short and Long Run Impacts of Cotton Price on Rural Poverty of Lialibé and Kossou Producers in Cote d'Ivoire
}

\author{
Kone Siaka", Noufou Coulibaly, Djina Djolo Jean Marc Junior \\ Management and Applied Economics Department, National Polytechnic Institute Houphouet Boigny, Yamoussoukro, Cote d'Ivoire
}

Email address:

ksiakawole@gmail.com (K. Siaka)

${ }^{*}$ Corresponding author

\section{To cite this article:}

Kone Siaka, Noufou Coulibaly, Djina Djolo Jean Marc Junior. Evaluation of Short and Long Run Impacts of Cotton Price on Rural Poverty of Lialibé and Kossou Producers in Cote d'Ivoire. International Journal of Agricultural Economics. Vol. 4, No. 5, 2019 , pp. $225-232$.

doi: $10.11648 /$ j.ijae.20190405.15

Received: July 28, 2019; Accepted: August 30, 2019; Published: September 17, 2019

\begin{abstract}
This paper measures, at the farm level, the short and long-term impacts of the fall in world cotton prices on agricultural incomes and the rural poverty level of cotton producers in Côte d'Ivoire. World cotton prices fell by $40 \%$ over the period from 2010 to 2018, this was felt by cotton producers. The objective of the paper is to show the relative importance of cotton for cotton producers and to draw the attention of public decision-makers to put in place public policies in the agricultural sector to support the development of the cotton sector. This paper combines farm survey data from Côte d'Ivoire with assumptions about the decline in farm-level prices to estimate the direct and indirect effects of cotton price reductions on rural income and poverty of Lialibé and Kossou Producers in Cote d'Ivoire. We used the monetary approach and the FosterGreer-Thorbecke method to measure poverty. The results indicate that there is a strong link between cotton prices and rural welfare of Lialibé and Kossou Producers in Cote d'Ivoire. A 36.11\% reduction in farm-level prices of cotton results in an increase in rural poverty of $30.43 \%$ points in the short run and $26-30 \%$ points in the long run according to elasticities. A $36.11 \%$ reduction in farm-level prices of cotton results in an increase in producer's income of $69 \%$ points in the short run and $50-69 \%$ points in the long run according to elasticities. Overall, the study demonstrates the impact of changes in world cotton prices on rural poverty in Côte d'Ivoire, thus highlighting the likely negative effects of cotton subsidies on Côte d'Ivoire farmers.
\end{abstract}

Keywords: Cotton, Price Impact, Poverty Index

\section{Introduction}

Ivorian agriculture employs more than $60 \%$ of the active population, it represents $34 \%$ of GDP and $2 / 3$ of export resources. In the $1960 \mathrm{~s}$, Côte d'Ivoire adopted cotton cultivation, mainly located in the northern and central regions, to (i) provide northern producers with a cash crop, (ii) reduce regional income disparities between the southern and northern areas, (iii) provide local textile industries with raw materials [1]. Cotton is a successful example of agricultural development. It has promoted income growth, poverty alleviation, improved food production through the support of national cotton structures and access to socio-economic infrastructure in the savannah areas of Côte d'Ivoire [2].
The world price of cotton is characterized by high volatility with a downward trend. Indeed, world cotton prices are characterized by a long-term downward trend [3]. The world price of cotton fell sharply from 2010 to 2018. Côte d'Ivoire exports more than $90 \%$ of its cotton production and appears to be highly dependent on the world market, its cyclical fluctuations and the agricultural policies implemented by competing countries [4]. Indeed, "world cotton production and trade are dominated by China, the United States and India. Nevertheless, the West and Central African region is the fifth largest cotton producer in the world and provides 5\% of total world production" [5].

Several authors have analyzed the impact of US, EU and Chinese agricultural policies on the world cotton price. Some 
countries provide very high levels of support to cotton producers. Since the signing of the Uruguay Round Agreement, the United States has implemented so-called less "distorting" agricultural policies, adopting the FAIR ACT in 1996 and the Farm Bill in 2002, which enshrined the use of several price support policies. These policies, although some of them are called "decoupled", reduce producers' risk aversion and result in overproduction [6]. Thus, "subsidies have the effect of maintaining production in countries with costs above market prices and forcing producers in countries without protective measures to adjust to low prices" [7].

Bale et al [8] have shown that agricultural policies in developing countries (protection) and developed countries (price support) have opposite effects with high social costs in both cases. These agricultural policies give a poor signal on the price level and distort resource allocations, production and consumption with negative consequences on trade patterns. Thus, some countries that should be net exporters become net importers and vice versa. Finally, Gillson et al [9] have shown that US cotton subsidies are responsible for lowering cotton producers' incomes in developing countries. In Côte d'Ivoire, the cotton sector is liberalized, there is no price support policy. Thus, cotton producers are left to their own devices in the absence of price support policies not otherwise authorized by the WTO. After all the players in the sector have recovered their margins, it is the residual value of the world price that goes to the producers. Producers thus constitute the adjustment variable of the world cotton price.

Studies show that there is a relationship between agricultural policies, prices, income and poverty levels. Minot and Daniel [10] analyzed the direct and indirect effects of the fall in cotton prices on poverty levels in Benin. Ravallion et al [11], measured the effect of a hypothetical reform of rice sector price and input support policy on poverty levels. Winters et al [12] have highlighted a mixed relationship between trade policies and poverty reduction. Liberalization implies a change in the distribution of wellbeing and can reduce the well-being of the poor.

In this article, we measure the short and long-term impact of a decline in cotton prices on the poverty level of farm households in rural areas. The research question is how does the decline in cotton prices influence agricultural income and poverty levels of agricultural households in the villages of Lialibé and Kossou in Côte d'Ivoire in the short and longterm. To answer this question, we hypothesize that if cotton is the main source of income in an area where other production alternatives are low or almost non-existent, a decrease in the price of cotton would lead to a decrease in agricultural income and an increase in the poverty level of agricultural households in the short and long term.

This paper is divided into five sections. At the end of the introduction, the second section is devoted to the presentation of the methodological approach adopted to measure the level of poverty. The third section presents the main results on the short and long-term impacts of the fall in cotton prices on agricultural income and the poverty level of agricultural households. The fourth section discusses the main findings of our study and the limitations of our research. Finally, the fifth section concludes this study with some observations and implications of the main findings.

\section{Methodology}

\subsection{Location of the Study Area}

The study covers the villages of Lialibé and Kossou located in the Bouaflé Department, located in the midwestern part of Côte d'Ivoire. The villages of Lialibé and Kossou are populated mainly by ethnic Senoufo allogens from northern Côte d'Ivoire in search of fertile land. These two villages are located in the intervention zone of the new CIDT (Compagnie Ivoirienne pour le Développement des Textiles) which is responsible for the modernization of cotton cultivation, the supply of inputs, the purchase, transport, ginning of seed cotton and the marketing of cotton fiber and seed. At the national level, the cotton sector in Côte d'Ivoire was managed by the CIDT created in 1974, which subsequently, in favor of the process of private liberalization between 1996 and 2000, was split into three blocks: CIDT Nouvelle, IC (Ivoire-Coton) and LCCI (La Compagnie Cotonnière Ivoirienne). Following a bankruptcy, LCCI was liquidated and acquired by OLAM-CI. There is a database regularly maintained on the production systems of these two villages by an agent of CIDT Nouvelle. Also, as part of a project funded by IDRC (International Development Research Centre) and led by ILRI (International Livestock Research Institute), there is a monitoring and data collection system for producers in these two villages on which we have based ourselves to obtain additional information necessary for our analysis. These databases focused on the production systems practiced by producers, i.e. the different crops practiced, the quantities of inputs applied.

\subsection{Data}

In order to complete the existing database, we conducted a face-to-face survey in 2018 with cotton producers in the villages of Lialibé and Kossou to collect data (production prices, areas, composition of agricultural households, etc.) on production systems. We surveyed one hundred (100) producers in the two villages. The data collection process was carried out in two phases: (i) the first consisted of comprehensive interviews with rural communities, with a view to building a dialogue with producers. Thus, the respondent can formulate his own questions, progress in his reflection and tell how he sees things, how he experiences them, from his point of view and from the point of view of his community; (ii) the second consisted in submitting the operators to a questionnaire composed of closed, semi-closed and open questions.

\subsection{Evaluation of the Short-term Impact of the Cotton Prices on Incomes}

We calculated the net farm incomes of cotton, maize and rice crops as the proxy variable for farm household incomes. 
We then calculated the family farm income per adult equivalent, which is the household income divided by the number of consumption units (CPU) in the household. The number of units in a household differs from the number of people in the household to consider the economies of scale that exist for some expenditures.

The calculation of the number of CUs in a household was done using the Central Statistics Office (CSO) method, the first adult in the household counts as a coefficient of 1 , persons over 14 years of age each count as a coefficient of 0.66 and persons under 14 years of age each count as a coefficient of 0.33 [13]. Equation 1 gives the agricultural income per adult equivalent.

$$
\mathrm{Y}_{\mathrm{i}}=\frac{\mathrm{RAF}_{\mathrm{i}}}{1+0,66 \cdot \mathrm{H}_{\mathrm{ai}}+0,33 \cdot \mathrm{H}_{\mathrm{ei}}}
$$

$Y i$; adult equivalent income of household $i$

$R A F i$ : family farm income of household $i$

$H_{a i}$; number of adults over 14 years of age in household $i$ excluding head of household $i$

Hei; number of children aged 14 or under in household $i$

The change in the adult equivalent income of household $i$ is the difference between pre-impact and post-impact income (equation 2). The year of the shock is 2010, after which the local cotton price has fallen steadily. The simulation is carried out at real rates of reduction in the local cotton price $(\triangle \mathrm{PC})$ observed in Côte d'Ivoire since 2010 of $10.3 \%, 15.4 \%$, $30.9 \%$ and $36.1 \%$.

$$
Y_{1 i}-Y_{0 i}=\frac{1}{H_{i}}\left(Q_{i} \cdot \Delta P C\right)
$$

Y1i; adult equivalent income of household $i$ after the shock

Yoi: adult equivalent income of household $i$ before the shock

Qi; quantity of cotton produced by household $i$

$\triangle P C$; price variation for cotton producers

Hi; equivalent size of household $i{ }_{(\mathrm{Hi}}=1+0.66 \mathrm{Hai}+$ $0.33 \mathrm{Hei})$

If a household does not produce cotton, $Q i=0$ so the price effect is zero $(Y 1 i=Y o i)$. If $Q i>0$, then a decrease in price $(\triangle P C<0)$ leads to a decrease in income $(\mathrm{Y} 1 \mathrm{i}<$ Yoi $)$.

\subsection{Evaluation of the Short-term Impact of the Cotton Prices on Poverty}

We have adopted the monetary approach to calculating the poverty level by considering the amount of one US dollar per (US\$1/day) as the poverty line. The impact of the change in price decline on poverty is calculated according to the poverty indicators of FGT (Foster-Greer-Thorbecke) [14]. This poverty index $\left(P_{\alpha}\right)$ is calculated according to equation 3 .

$$
\mathrm{P}_{\alpha}=\frac{1}{\mathrm{~N}} \sum_{1}^{\mathrm{N}_{\mathrm{p}}}\left[\frac{\mu-\mathrm{Y}_{\mathrm{pi}}}{\mu}\right]^{\alpha}
$$

Np: Number of households below the poverty line No.: Number of households above the poverty line $N$ : Total number of households $(N=N p+N r)$ $\mu$ : Poverty line Poverty line

$Y_{p i}$ Adult equivalent income of a poor household $\mathrm{i}$

The $\alpha$ parameter takes the values 0,1 or 2 .

1. If $\alpha=0$, the poverty index P0 measures the poverty rate, which is the proportion of households whose income is below the poverty line: $P_{0}=\frac{N_{p}}{N}$;

2. If $\alpha=1$, the poverty index P1 measures the intensity of poverty which expresses the average income gap of the poor relative to the poverty line;

3 . If $\alpha=2$, the ${ }_{\mathrm{P} 2}$ poverty index measures the severity of poverty, which gives a measure of inequality among the poor [15] and [16].

\subsection{Evaluation of the Long-term Impact of the Cotton Prices on Producers Welfare}

When the price falls from PC1 to PC2, the change in producer Welfares measured by the change in producer surplus materialized by the sum $(\mathrm{A}+\mathrm{B})$ of the hatched areas in Figure 1 and calculated according to Equation 4.

$$
\Delta S P=\Delta P C \cdot Q_{2}+\frac{1}{2} \cdot(\Delta P)^{2} \cdot \varepsilon \cdot \frac{Q_{1}}{P C_{1}}
$$

PC: cotton price

Qi; quantity of cotton produced by household $i$

$\varepsilon$; elasticity of the quantity offered in relation to the price of cotton

SP: producer surplus

$\Delta S P$; variation of the producer's surplus

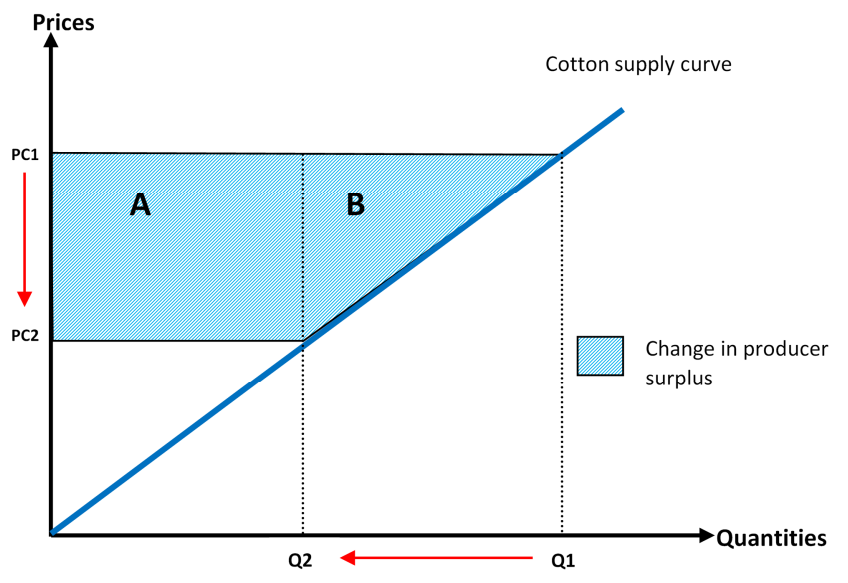

Figure 1. Change in producer surplus.

Equation 5 gives the variation in welfare.

$$
Y_{1 i}-Y_{0 i}=\frac{1}{H_{i}}\left[\left(\Delta P C \cdot Q_{2 i}\right)+\frac{1}{2}(\Delta P C)^{2} \varepsilon \frac{Q_{1 i}}{P C_{1}}\right]
$$

$\mathrm{Y}_{1 \mathrm{i}}$ : adult equivalent income of household $\mathrm{i}$ after the shock

$\mathrm{Y}_{\mathrm{oi}}$ : adult equivalent income of household $\mathrm{i}$ before the shock

$\mathrm{Q}_{i}$; quantity of cotton produced by household $\mathrm{i}$

$\triangle \mathrm{PC}$; variation in cotton prices

$\mathrm{Hi}$; equivalent size of household $\mathrm{i}$

$\mathcal{E}$ elasticity of the quantity of cotton $\mathrm{Q}$ in relation to the price of cotton 
In the absence of an estimate of the elasticities of the villages of Lialibé and Kossou, we adopt four plausible values of elasticity, namely $0 ; 0.5 ; 1$ and 1.5 . They allow us to perform sensitivity analyses of our results [10].

\section{Results}

\subsection{Characteristics of Agricultural Households}

The age of the producers varies from 26 to 70 years with an average of 43 years (Table 1 ).

Table 1. Characteristics of farm households surveyed in 2018.

\begin{tabular}{|c|c|c|c|c|c|c|c|}
\hline \multirow{2}{*}{ Features and characteristics } & \multirow{2}{*}{ Age } & \multirow{2}{*}{ Women } & \multirow{2}{*}{ Children } & \multirow{2}{*}{ Other parents } & \multicolumn{3}{|c|}{ Persons in the household of } \\
\hline & & & & & {$[0 ; 14]$} & {$[15 ; 64]$} & {$[65 ;+]$} \\
\hline Total & $(-)$ & 68 & 247 & 35 & 144 & 204 & 2 \\
\hline Average & 43 & 2 & 7 & 1 & 4 & 6 & 0 \\
\hline Proportion (\%) & $(-)$ & 17.66 & 64.16 & 9.09 & 37.40 & 52.99 & 0.52 \\
\hline Min & 26 & 1 & 1 & 0 & 0 & 1 & 0 \\
\hline Max & 70 & 5 & 20 & 9 & 18 & 18 & 1 \\
\hline Standard deviation & 12.18 & 1.06 & 4.45 & 1.78 & 3.07 & 4.32 & 0.24 \\
\hline
\end{tabular}

(-); these values do not exist. Source: authors' calculations

\subsection{Cultivation System}

The main speculations are cotton, maize and rice. Cotton (182 ha) is the most important, followed by maize (180 ha) and rice (43.25 ha) (Table 2). Cotton cultivation occupies an important place ( $45 \%$ of the surface area) in the production systems of Lialibé and Kossou. Market gardening is practiced marginally by women and perennial crops are not practiced because the land does not belong to producers who are all non-indigenous. This effectively restricts the alternative choices of these producers.

Table 2. Main crops grown by producers in 2018

\begin{tabular}{lllllll}
\hline \multirow{2}{*}{ Designation } & Surfaces (ha) & & & \multicolumn{2}{c}{ Productions (T) } \\
\cline { 2 - 6 } & Cotton & Corn & Rice & Cotton & Corn \\
\hline Total & 182.5 & 180 & 5.1 & 43.2 & 205.3 & 52.6 \\
Average & 5.2 & 0.5 & 1.2 & 5.87 & 29.7 \\
Min & 1 & 25 & 0 & 1 & 1.3 & 0.1 \\
Max & 25 & 44.4 & 10 & 24 & 5 & \\
Proportion (\%) & 45.0 & 10.7 & 71.4 & 18.3 \\
\hline
\end{tabular}

Maize acreage is not increasing in the same proportion as the decline in cotton acreage (Figure 2). In 2018, cotton occupied $63 \%$ of the surface area and maize $34 \%$, compared to $45 \%$ and $44 \%$ respectively for cotton and maize. We also noticed a decrease in the total surface area. This reflects the difficulty of producers in Lialibé and Kossou to reallocate cotton areas to other speculation despite the fall in prices.

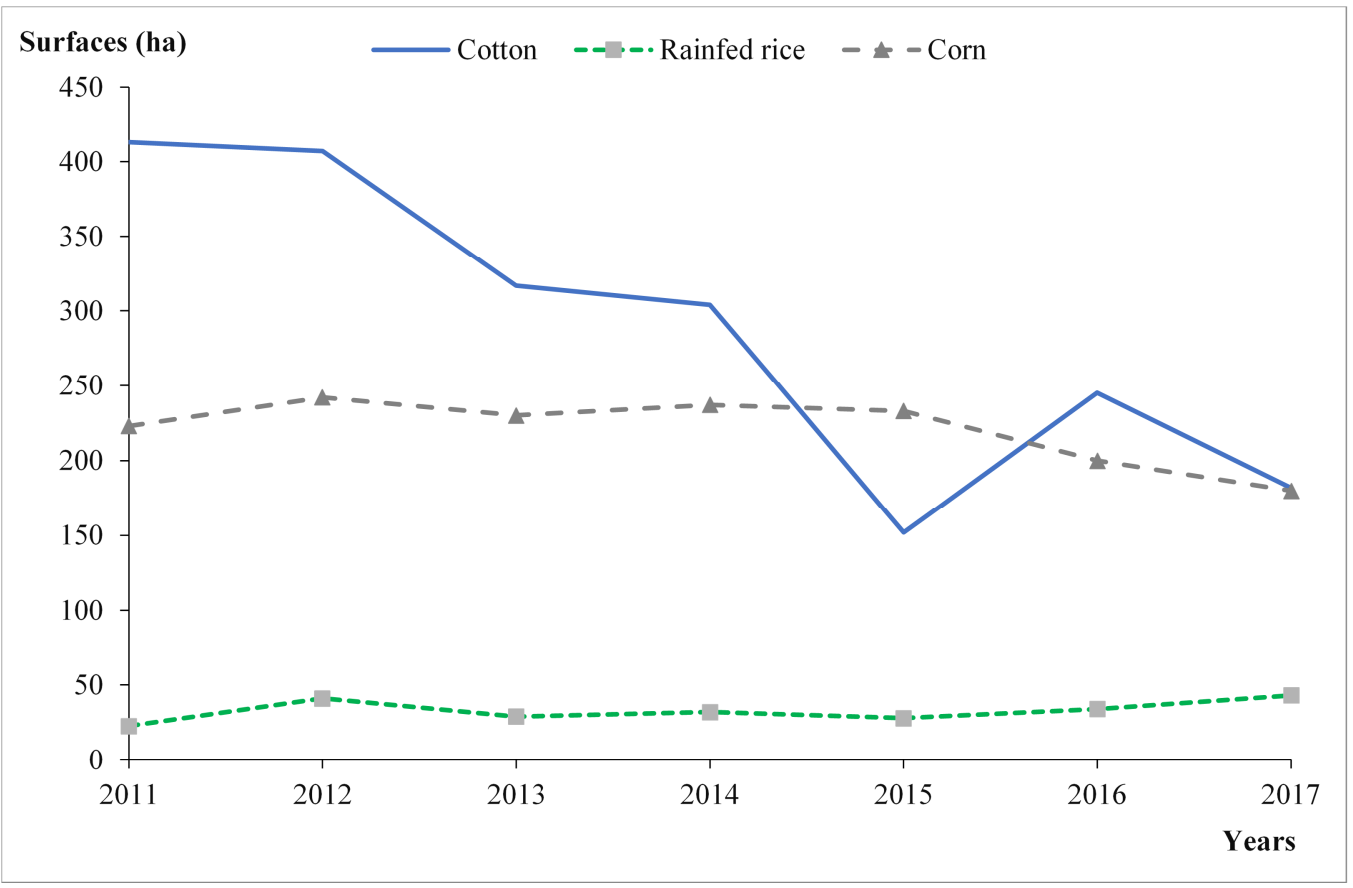

Figure 2. Evolution of surfaces from (2010 to 2018). 


\subsection{Short-term Impact of the Cotton Prices on Incomes and Poverty}

A drop in cotton prices of $10.3 \%$ and $15.4 \%$ leads to a drop in income of $19.7 \%$ and $29.6 \%$ respectively (Table 3 ). A $36.1 \%$ reduction in the price to cotton producers results in a
$69.1 \%$ drop in income in the short term, a $30.43 \%$ increase in the poverty rate (P0) from $60.8 \%$ to $91.3 \%$, an increase in poverty intensity ( $\mathrm{P} 1)$ from 0.4 to 0.7 , and an increase in the severity of poverty (P2) from 0.34 to 0.70 .

Table 3. Short-term impact of the cotton price reduction.

\begin{tabular}{lllll}
\hline \multirow{2}{*}{ Indicators } & \multicolumn{2}{l}{ Rate of price change (\%) } \\
\cline { 2 - 5 } & Base & $\mathbf{1 0 . 3 2}$ & $\mathbf{1 5 . 4 8}$ & $\mathbf{3 0 . 9 5}$ \\
\hline Adult Equivalent Income (FCFA) & 154260 & 123817 & 108595 & 62930 \\
Rate of change in income & $(-)$ & $-19.74 \%$ & $-29.60 \%$ & $-59.21 \%$ \\
Poverty rate (P0) & $60.87 \%$ & $82.61 \%$ & $82.61 \%$ & $86.96 \%$ \\
Poverty intensity (P1) & 0.41 & 0.49 & 0.53 & $-69.07 \%$ \\
Severity of poverty (P2) & 0.34 & 0.41 & 0.45 & 0.68 \\
\hline
\end{tabular}

(-); no change. Source: authors' calculations

The intersection between the vertical line (poverty line) and the income curves indicates the poverty rate (Figure 3). We note that the lower the price of cotton and the further away the curves are from the abscissa axis, this reflects an increase in the poverty rate.

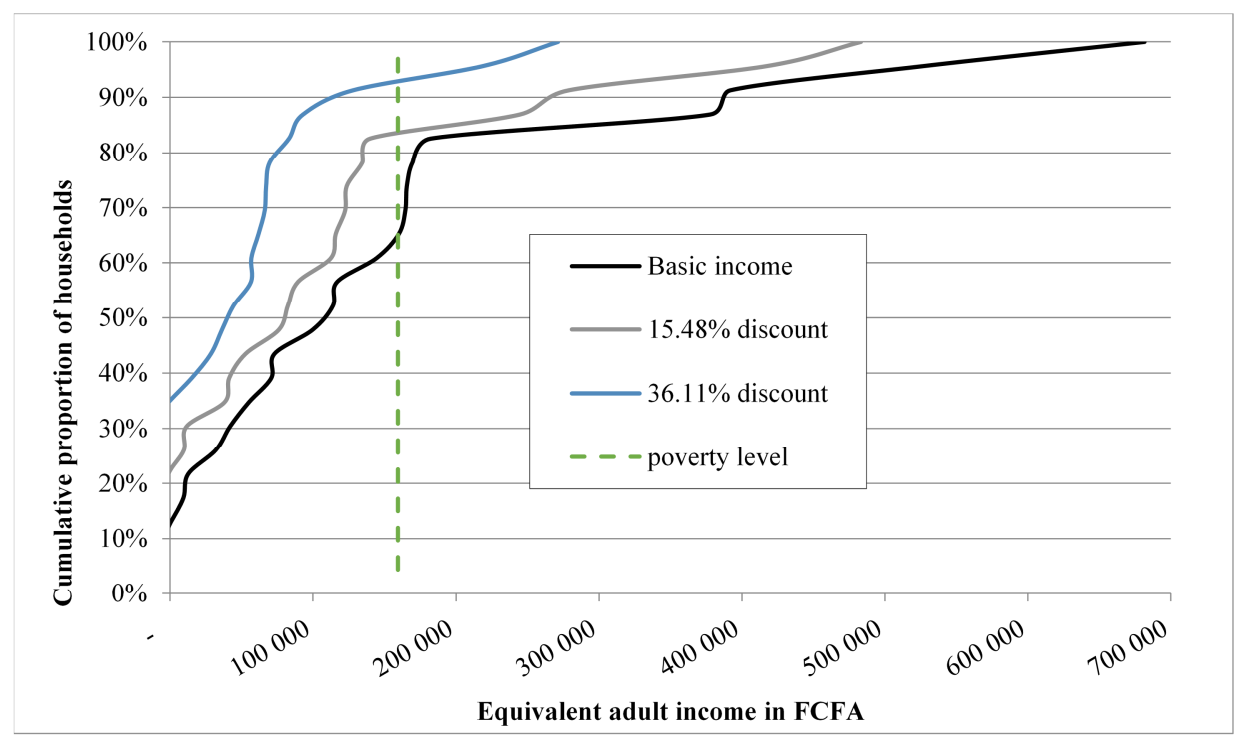

Figure 3. Short-term impact on the cumulative distribution of income.

The higher the poverty line, the higher the poverty rate (Table 4). The level of poverty is sensitive to changes in poverty lines.

Table 4. Effects of different poverty lines on poverty level.

\begin{tabular}{llll}
\hline \multirow{2}{*}{ Indicators } & Different annual poverty lines & \\
\cline { 2 - 4 } & Minot & One dollar/day & World Bank \\
\hline Poverty rate (P0) & $43 \%$ & $61 \%$ & $83 \%$ \\
Poverty intensity (P1) & 0.30 & 0.41 & 0.54 \\
Severity of poverty (P2) & 0.28 & 0.34 & 0.42 \\
\hline
\end{tabular}

Source: authors' calculations

\subsection{Long-term Impact of Lower Cotton Prices on Incomes and Poverty}

A $36.1 \%$ drop in cotton prices leads to a long-term decline of $69.1 \%, 62.8 \%, 56.6 \%, 50.4 \%$ respectively for elasticities of $0,0.5 ; 1$ and 1.5 (Table 5). Over the long term, a $36.1 \%$ price decrease according to elasticities creates a $26 \%$ to $30 \%$ increase in the poverty rate (P0), 0.41 to 0.75 of the poverty intensity (P1) and 0.34 to 0.70 of the depth of poverty (P2).
The long-term effect of the price decrease seems weaker than in the short term, because when prices fall in the short term, producers do not have time to adjust their production plan, the quantities offered remain unchanged and losses are higher. On the other hand, in the long term, producers make the necessary adjustments (reallocation of land or reduction in area, etc.) that reduce area and production. The loss recorded will be lower than in the short term. 
Table 5. Long-term impact of a $36.1 \%$ price decrease.

\begin{tabular}{|c|c|c|c|c|c|}
\hline \multirow{2}{*}{ Indicators } & \multirow{2}{*}{ Base } & \multicolumn{4}{|c|}{ Elasticities ( $(\varepsilon)$} \\
\hline & & $\mathbf{0}$ & 0,5 & 1 & 1,5 \\
\hline Adult Equivalent Income (FCFA) & 154260 & 47708 & 57327 & 66946 & 76566 \\
\hline Rate of income reduction & $(-)$ & $-69.07 \%$ & $-62.84 \%$ & $-56.60 \%$ & $-50.37 \%$ \\
\hline Poverty rate $(\mathrm{P} 0)$ & $60.87 \%$ & $91.30 \%$ & $91.30 \%$ & $86.96 \%$ & $86.96 \%$ \\
\hline Poverty intensity (P1) & 0.41 & 0.75 & 0.70 & 0.67 & 0.63 \\
\hline Severity of poverty $(\mathrm{P} 2)$ & 0.34 & 0.70 & 0.64 & 0.60 & 0.56 \\
\hline
\end{tabular}

(-): no change in income. Source: authors' calculations

In the long term, there is an inverse relationship between the price elasticity of supply and the effect of lower cotton prices (Figure 4). Indeed, the higher the elasticity, the more sensitive producers are to price variations; they then tend to reduce further the quantity of cotton produced and at the same time cushion the negative effects of lower prices in the long term after a reallocation of land.

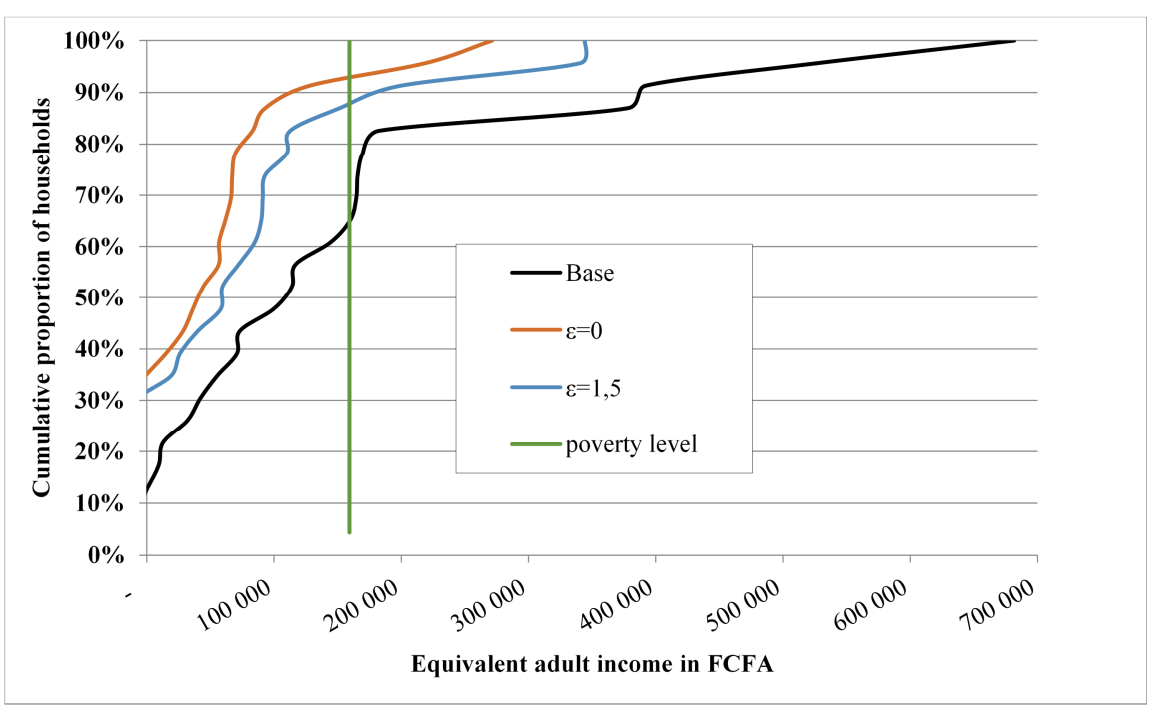

Figure 4. Long-term impact on the cumulative distribution of income (at $36.1 \%$ ).

\section{Discussions}

Compared to the work of Minot and Daniel [10], our results show a higher sensitivity of the poverty level to the fall in cotton prices. Indeed, the results of these authors show that a $40 \%$ drop in cotton prices leads to an increase in rural poverty in Benin of $8 \%$ in the short term and 6 to $7 \%$ in the long term. Our results show that a $36 \%$ decline leads to a $30 \%$ increase in poverty levels in the short term and a $26 \%$ to $30 \%$ increase in the long term. This difference in sensitivity is partly explained by the choice of the proxy variable for farm household income. Indeed, while Minot and Daniel [10] retained consumer spending as the proxy for income, we chose net farm income for cotton, corn and rice crops. Thus, when the producer price is below the break-even point, the net income is negative and the number of producers with negative incomes is identified in the model as the number of poor.

In addition, a study on the development recovery and poverty reduction strategy carried out by the Ministry of Planning and Development in 2009 in Côte d'Ivoire measured poverty through its monetary dimension, which is based on the well-being indicator and a poverty line of CFAF 661 per day. The results show a rural poverty rate of $62.45 \%$ in 2008 for the whole of Côte d'Ivoire, and $56.0 \%$ in the midwestern part of Côte d'Ivoire (where the villages of Lialibé and Kossou are located) [17]. Our results are relatively close to the conclusions of this study.

In their work Orden [18], they analyzed the impact of cotton prices on the level of rural poverty in Pakistan. They hypothesize that the increase in the level of poverty is due to the fall in the prices of raw materials (cotton, meat, rice and sugar). They adopted a monetary approach to measuring poverty level and considered the amount of expenditure as the proxy variable for producers' farm income. They result in a level of rural poverty of $40 \%$. Simulations show that a $20 \%$ increase in cotton prices reduces poverty levels by 25 and $22 \%$ respectively in Punjab and Sindh localities in Pakistan. These results show, as our study shows, that the cotton price influences incomes and poverty levels.

Cotton areas fell by $63 \%$ from 2010 to 2018 without any increase in other crop areas (rice or maize) to compensate for this decline in cotton areas. This results in a reduction in the size of farms and therefore possible losses in terms of farm income. If producers had other opportunities, they would have reallocated labor force and resources to other activities, which is not the case here. A plausible explanation for this phenomenon is that cotton remains the only crop that benefits 
from a secure market and framework. Producers face constraints (sales difficulties, landlockedness, lack of a solid peasant organization) for the extension of other crops that could be alternatives to cotton. This reality is common to many cotton production areas in Africa. Indeed "cotton production is practiced by nearly 3 million West African households and some 16 million people directly or indirectly dependent on this crop. This crop is particularly important in the Sudano-Sahelian areas of West Africa where alternatives for other cash crops as well as for other profitable nonagricultural activities are few" [5].

Despite the sharp drop in cotton from 2010, cotton producers in the villages of Lialibé and Kossou have not completely abandoned cotton cultivation in favor of other crops. There are several explanations for this paradox. The cotton sector is the only structuring sector, it benefits from a service of supervision, supply of inputs and agricultural equipment, access to credits, which are used on other crops in the producer's production system. Thus, cotton cultivation has for a very long time been the "driving force" behind the development of producer's production systems. This gave it the name of the cotton system. Belonging to the "cotton system" allows producers to access production factors that are often "diverted" to be applied to other food crops (maize, rice, etc.) essential for the food security of agricultural households. Nubukpo [19] calls this phenomenon "the cotton trap". In addition, cotton producers face market and factor supply constraints for the development of other alternative crops to cotton (Figure 2). The decision to reallocate cotton areas to other crops faces severe constraints. Today, with the food crisis that most African countries have experienced, still timid actions to diversify food crops are underway in most West and Central African countries.

The equivalent size of households could influence our results. Indeed, adult equivalized income is an inverse function of the equivalent household size $\mathrm{Hi}$. Thus, the fewer individuals in the household, the higher the adult equivalized income and the lower the poverty level. The reality is more complex, however, as members of the household constitute the labor force essential to the development of the plots. Thus, the more individuals in the household, the more labor is available to the head of the production unit in a context where the agricultural sector is weakly mechanized.

We can list some of the limitations of our work. First, we assumed that the price of other speculations does not change. In practice, the prices of these speculations can vary and impact our results. Considering the net incomes of the three main speculations (cotton, maize and rice) as the proxy variable for agricultural income is questionable insofar as some producers could receive financial resources from other activities (livestock, trade, etc.) or donations from any family member. Taking these additional resources into account could affect our results, but only slightly. In our analysis, we ignored the imperfect transmission between the international market price of cotton fiber and the price of seed cotton paid to cotton producers. Seed cotton is produced by cotton producers, then ginned by cotton companies, which then market the seed and cotton fiber. The difference between the producer price and the international price of cotton corresponds to the fees and charges of the cotton sector, industrial and commercial costs. The various levies by cotton structures influence the level of prices paid to producers by reducing their income level. Thus, the producer becomes a cotton price adjustment variable, as they receive the residual value of the international cotton price once all levies are made by cotton companies and regulatory institutions. Finally, our study is contextualized by both the period of analysis and the region examined.

\section{Conclusion}

The analysis of the impact of the fall in cotton prices on cotton producers in the villages of Lialibé and Kossou in Côte d'Ivoire is motivated by the volatility of cotton prices, which is characterized by a downward trend, while cotton plays a key role for these producers. Using the data collected, we analyzed the characteristics of producers and assessed the short- and long-term impact of the fall in cotton prices on incomes and poverty levels. Our results confirm our hypothesis that cotton is the main source of income and that the decline in cotton prices leads to a decrease in agricultural income and an increase in the short- and long-term poverty level of agricultural households in the villages of Lialibé and Kossou in Côte d'Ivoire. Thus, this article highlights the crucial role that cotton plays as a vector for poverty alleviation for cotton producers in the villages of Lialibé and Kossou. The decline in income observed while increasing "monetary poverty" leads to "capacity poverty", as producers facing a drastic drop in income from the main cash crop (cotton) will be increasingly vulnerable and will have difficulty accessing primary needs (health, schooling of children, food, etc.) and factors of production. As a result, producers in the villages of Lialibé and Kossou could find themselves in a spiral of poverty.

Our results show that cotton is essential for African producers who have little or no alternatives for other cash crops in the short term. Thus, the short-term strategy would be to put in place emergency and specific policies to support the prices of African cotton producers within the framework of the special differential treatment granted to developing countries at WTO level. In the medium and long term, it is desirable to take measures within the WTO to stop support for cotton-producing countries with distortions on the world cotton market. The current Doha Round trade negotiations provide a good opportunity to remove agricultural policies that distort international trade in agricultural products, including cotton, relatively quickly.

\section{References}

[1] Berté, K. and F. M. Epplin, Evaluation of the influence of agricultural price policy on cotton production in Côte-d'Ivoire. Agricultural Economics, 1989. 3 (1); p. 69-76. 
[2] Zagbai, H. S., F. Berti, and P. Lebailly, Impact de la dynamique cotonnière sur le développement rural. Étude de cas de la région de Korhogo, au Nord et au Centre de la Côte d'Ivoire. Biotechnologie, Agronomie, Société et Environnement, 2006. 10 (4); p. 325-334.

[3] Berti, F., et al., Le coton dans le monde, place du coton africain et principaux enjeux. Biotechnologie, Agronomie, Société et Environnement, 2006. 10 (4); p. 271-280.

[4] Perrin, S. and D. Lagandre, Le coton africain face à la concurrence du marché mondial. 2005, AFD: 75012 Paris France. p. 33

[5] CSAO/OCDE, Le coton en Afrique de l'Ouest un enjeu économique et social, ed. OCDE. 2006, Paris. 131.

[6] Burfisher, M. E., S. Robinson, and K. Thierfelder, North American Farm Programs and the WTO. American Journal of Agricultural Economics, 2000. 82 (3); p. 768-774.

[7] Estur, G., Le marché mondial du coton; évolution et perspectives. Cahiers Agricultures, 2006. 15, n 1 (1); p. 8.

[8] Bale, M. D. and E. Lutz, Price Distortions in Agriculture and Their Effects: An International Comparison. American Journal of Agricultural Economics, 1981. 63 (1); p. 8-22.

[9] Gillson, I., et al., Understanding the impact of Cotton Subsidies on developing countries. 2004 World Bank: Washington DC. p. 74.

[10] Minot, N. and L. Daniels, Impact of global cotton markets on rural poverty in Benin. Agricultural Economics, 2005. 33 (s3); p. $453-466$.

[11] Ravallion, M. and D. Van De Walle, The impact on poverty of food pricing reforms: A welfare analysis for Indonesia. Journal of Policy Modeling, 1991. 13 (2); p. 281-299.

[12] Winters, L. A., N. Mcculloch, and A. Mckay, Trade Liberalization and Poverty; The Evidence so Far. Journal of Economic Literature, 2004. 42 (1); p. 72-115.

[13] SENAT, La mesure de la pauvreté et de l'exclusion sociale; quels indicateurs?, in Etudes Economiques. 2007, Senat: Paris. p. 67.

[14] Foster, J., J. Greer, and E. Thorbecke, A Class of Decomposable Poverty Measures. Econometrica, 1984. 52 (3); p. 761-766.

[15] Grimm, M., C. Guenard, and S. Mesple-Somps, Evolution de la pauvreté urbaine en Côte d'Ivoire; Une analyse sur 15 ans d'enquêtes ménages. 2001, DIAL - UR CIPRE de l'IRD. p. 41.

[16] PNUD, Mesure de la pauvreté selon la méthode de degré de satisfaction des besoins essentiels; expérience du Niger. 2007, PNUD: Niger. p. 214.

[17] Ministère du plan et du développement, Stratégie de relance du développement et de réduction de la pauvreté (DSRP). 2009: Côte d'Ivoire. p. 198.

[18] Orden, D., et al., The Impact of Global Cotton Markets on Rural Poverty in Pakistan, in American Agricultural Economics Association Annual Meeting. 2006: California. p. 25.

[19] Nubukpo, K. K., Le piège du coton; le Mali à la croisée des chemins. Oléagineux, Corps Gras, Lipides, 2006. 13 (4); p. 278-84. 